\title{
Review \\ Sulphate-Reducing Bacteria's Response to Extreme pH Environments and the Effect of Their Activities on Microbial Corrosion
}

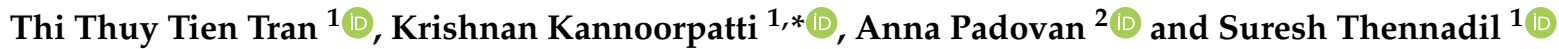 \\ 1 Energy and Resources Institute, College of Engineering, Information Technology and Environment, \\ Charles Darwin University, Darwin, NT 0909, Australia; tien.tranthithuy@cdu.edu.au (T.T.T.T.); \\ suresh.thennadil@cdu.edu.au (S.T.) \\ 2 Research Institute for the Environment and Livelihoods, College of Engineering, Information Technology and \\ Environment, Charles Darwin University, Darwin, NT 0909, Australia; anna.padovan@cdu.edu.au \\ * Correspondence: krishnan.kannoorpatti@cdu.edu.au
}

Citation: Tran, T.T.T.; Kannoorpatti,

K.; Padovan, A.; Thennadil, S.

Sulphate-Reducing Bacteria's

Response to Extreme $\mathrm{pH}$

Environments and the Effect of Their Activities on Microbial Corrosion. Appl. Sci. 2021, 11, 2201. https:// doi.org/10.3390/app11052201

Academic Editor: Hoon Kim

Received: 1 February 2021

Accepted: 26 February 2021

Published: 3 March 2021

Publisher's Note: MDPI stays neutral with regard to jurisdictional claims in published maps and institutional affiliations.

Copyright: (c) 2021 by the authors. Licensee MDPI, Basel, Switzerland. This article is an open access article distributed under the terms and conditions of the Creative Commons Attribution (CC BY) license (https:// creativecommons.org/licenses/by/ $4.0 /)$.

\begin{abstract}
Sulphate-reducing bacteria (SRB) are dominant species causing corrosion of various types of materials. However, they also play a beneficial role in bioremediation due to their tolerance of extreme $\mathrm{pH}$ conditions. The application of sulphate-reducing bacteria (SRB) in bioremediation and control methods for microbiologically influenced corrosion (MIC) in extreme $\mathrm{pH}$ environments requires an understanding of the microbial activities in these conditions. Recent studies have found that in order to survive and grow in high alkaline/acidic condition, SRB have developed several strategies to combat the environmental challenges. The strategies mainly include maintaining $\mathrm{pH}$ homeostasis in the cytoplasm and adjusting metabolic activities leading to changes in environmental $\mathrm{pH}$. The change in $\mathrm{pH}$ of the environment and microbial activities in such conditions can have a significant impact on the microbial corrosion of materials. These bacteria strategies to combat extreme $\mathrm{pH}$ environments and their effect on microbial corrosion are presented and discussed.
\end{abstract}

Keywords: sulphate-reducing bacteria; survival; $\mathrm{pH}$; microbial corrosion

\section{Introduction}

Sulphate-reducing bacteria (SRB) are a group of microorganisms that utilise sulphate as a terminal electron acceptor for anaerobic respiration. They play essential roles in sulphur and carbon cycles. The ability of SRB to convert sulphate to sulphide has been used widely for bioremediation which is a low-cost technique for the treatment of acid mine tailings. On the other hand, SRB are the chief culprits that account for microbiologically influenced corrosion (MIC). Understanding SRB metabolic activities in different environments is essential to propose suitable processes for SRB application in bioremediation as well as controlling MIC.

Environmental $\mathrm{pH}$ is one of the main factors that strongly influences microbial metabolic activities and bacterial communities [1,2]. $\mathrm{pH}$ affects bacterial metabolism through different ways, including changing environmental conditions for bacteria growth, affecting bacterial extracellular enzyme activities, disturbing the growth rate of bacterial metabolism. $\mathrm{pH}$ can influence the concentration of nutrients as the concentration of protons and hydroxyls can affect nutrient dissolution, precipitation and geochemical reactions leading to the increase or decrease of the nutrient for bacteria to growth. Researchers have reported the dependence of bacterial extracellular enzymes on $\mathrm{pH}$, with increasing environmental $\mathrm{pH}$ resulting in reduced enzymatic capacity for degrading organic substrates [3,4]. Environmental $\mathrm{pH}$ was also found to strongly influence bacterial growth rates with a one-unit deviation from optimum $\mathrm{pH}$ resulting in a $50 \%$ decrease in bacterial growth rate and lowering microbial metabolism by up to $50 \%$. The thermodynamic and kinetic responses to $\mathrm{pH}$ in microbial respirations have been studied by Jin and Kirk $[5,6]$. 
It has been known for a long time that SRB prefer to grow at $\mathrm{pH}$ range 6-8 [7]. However, SRB occur in acidic environments [8,9] and alkaline environments [10-13]. SRB can be divided into three groups based on their optimum environmental $\mathrm{pH}$ for growth: acidophilic, alkaliphilic and neutrophilic. Acidophilic SRB have been found to be able to grow at pH 2.9 to 6.5 [14-16]. Alkaliphilic SRB grow optimally in extremely alkaline environments from $\mathrm{pH}$ of 6.9 to 9.9 [13]. Neutrophilic SRB species are better known than acidophilic and alkaliphilic SRB and thought to be only able to grow at $\mathrm{pH}$ range 6-8 [7]. However, later studies found that neutrophilic SRB could also survive and grow in extreme $\mathrm{pH}$ conditions $[17,18]$ and current bioremediation treatment of acid mines mainly use neutrophilic SRB which is highly sensitive to acidic environment [19].

Extreme $\mathrm{pH}$ environments can be human-made, e.g., acid mine tailings, or natural, such as alkaline ground waters and there are many places that equipment have been working under such conditions. After time of exposure to these conditions, the life expectancy of equipment materials might be reduced due to the deterioration of materials caused by corrosion. The existence of bacteria in these environments also causes MIC, especially with $\mathrm{SRB}$, the dominant species accounting for MIC. Thus, corrosion under these conditions is caused by the combined effect of environmental $\mathrm{pH}$ on corrosion, bacteria metabolism for their survival and growth which have effect on microbial corrosion. Understanding survival ability of SRB in extreme $\mathrm{pH}$ environment can propose a suitable mechanism of MIC caused by SRB in such conditions and possible mitigation methods for corrosion.

MIC of metals is influenced by a number of conditions including the type of metal, temperature, $\mathrm{pH}$, flow conditions, applied voltage, coatings, biocides, and hydrophobicity. However, $\mathrm{pH}$ of the environments presents some issues that have not been discussed widely in MIC literature. The goal of this present work is to elucidate and summarise existing knowledge on how neutrophilic SRB survive and grow under extreme $\mathrm{pH}$ conditions, including sulphate reduction activities, and its effect on material corrosion.

\section{Sulphate Reduction Metabolism}

In anoxic habitats, SRB generally use sulphate as an electron acceptor for anaerobic respiration and gaining energy for growth. The source of the electron donor can come from the oxidation of a carbon source, hydrogen or metal. The process of sulphate reduction occurs through a dissimilatory sulphate reduction (DSR) metabolic pathway catalysed by enzymes. Generally, the DSR process includes four steps (Figure 1). The first step is the activation of free sulphate around bacterial cells by the enzyme sulphate adenylyltransferase (ATP-sulfurylase) to produce adenosine-5-phosphosulfate (APS) and pyrophosphate (PPi). The potential of sulphate/sulphite is too negative $(-516 \mathrm{mV})$ for reduction by NADH or ferredoxin which are the primary intracellular electron mediators [20]. The next step is the reduction of cytoplasmic APS to sulphite/bisulphite and adenosine monophosphate (AMP) by the enzyme APS reductase. Then, sulphite is catalytically reduced to the DsrC trisulphide intermediate by the dissimilatory sulphite reductase (DsrAB) enzyme. The final step is the reduction of trisulphide to sulphide and reduced $\mathrm{DsrC}_{\mathrm{r}}$ by a membrane bound enzyme DsrMKJOP complex. The steps described above are shown in Figure 1.

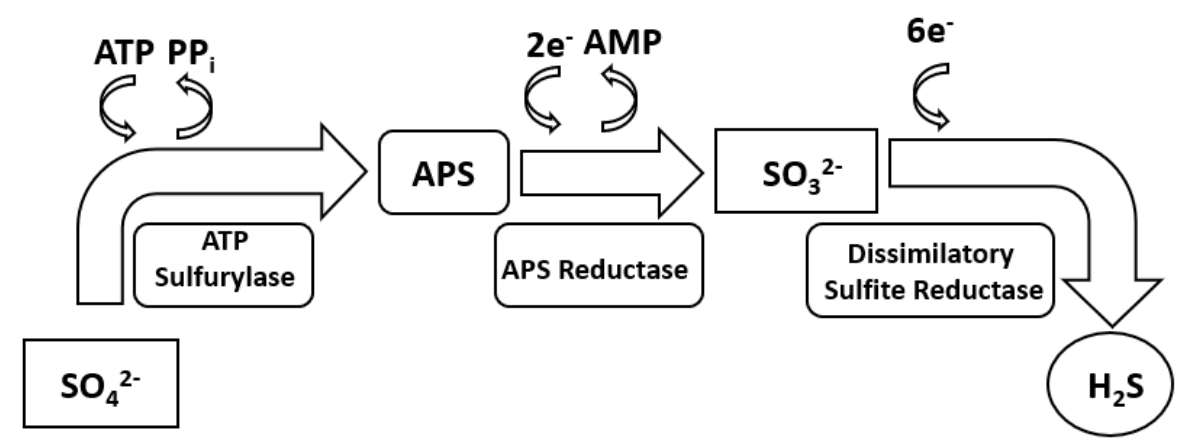

Figure 1. Dissimilatory sulphate reduction in sulphate-reducing bacteria (SRB) [21]. 
SRB metabolic activities have been shown to be related to environmental conditions [22]. The metabolic flexibility of SRB helps to increase their chance of survival when environmental conditions change, for instance, the respiration of a group of Desulfobvibrio sp. under aerobic conditions where the same substrate as sulphate are oxidised with oxygen [23].

Another example is the survival and growth of SRB in sulphate depleted environments. Bryant et al. [24] reported Desulfovibrio sp. was able to grow with methanogenic bacteria in the absence of sulphate. A product of SRB metabolic activity is $\mathrm{H}_{2}$ which can be consumed by methanogenic bacteria. This coexistence helps SRB to obtain enough energy for their survival and growth. The coexistence of SRB and other microorganisms was also found in extreme $\mathrm{pH}$ environments where the metabolism of the other microorganism changes the $\mathrm{pH}$ to a suitable level for growth [24]. Sulphate reducers also have their own strategy to survive and grow in extreme $\mathrm{pH}$ environments. The following sections explain their strategy to adapt to acidic environments.

\section{SRB Activities in Acidic Environments}

Acidic habitats can be found in acidic lakes and rivers, and acidic wetlands containing high concentrations of organic acids, as well as mine tailings. The presence of neutrophilic SRB and sulphate reduction activities in acidic habitats, especially with $\mathrm{pH}$ below 5 have been found since the last decades $[25,26]$. D. vulgaris and Desulfovibrio caledoniensis were reported to increase their environmental $\mathrm{pH}$ from 4 to 7.4 and 6 to around 7.5 , respectively [27].

\subsection{Response of SRB to Acidic Environments}

In extreme acidic conditions, SRB develop adaptive strategies to adapt to the environmental condition. The strategies may include: maintain suitable $\mathrm{pH}$ in cytoplasm, regulate protein synthesis, change metabolic pathways.

\subsubsection{The Maintenance of $\mathrm{pH}$ in Cytoplasm}

When exposed to acidic conditions, most neutrophilic bacteria need to sustain a compatible cytoplasmic $\mathrm{pH}$ that lies within $\mathrm{pH}$ of 7.4-7.8 $[28,29]$ to maintain $\mathrm{pH}$ homeostasis with optimum function and structural integrity of the cytoplasmic proteins to support their growth [30]. Then, they are able to neutralize the $\mathrm{pH}$ of the cytoplasm relative to the external $\mathrm{pH}$ condition. The maintenance of cytoplasmic $\mathrm{pH}$ can be done by restricting proton permeation, increasing pumping proton out of cytoplasm and increase proton consumption.

\section{Restriction of Proton Permeation}

Proton from environment go into bacteria cytoplasm via plasma membrane. The driven force of proton flow or proton motive force (pmf) is generated by the proton electrochemical potential difference $\left(\Delta \mu_{H^{+}}\right)$which can be calculated by membrane potential difference $(\Delta \psi)$ and $\mathrm{pH}$ gradient $(\Delta p H)$ across a membrane [28].

$$
\Delta \mu_{H^{+}}=F \Delta \psi-2.3 R T \Delta p H
$$

where $F$ is Faraday constant $\left(96,480 \mathrm{JV}^{-1} \mathrm{~mol}^{-1}\right), R$ is the gas constant $\left(8.315 \mathrm{JK}^{-1} \mathrm{~mol}^{-1}\right)$ and $T$ is temperature $(\mathrm{K})$. Membrane potential difference $(\Delta \psi)$ is generated as a result of the transfer of protons. When the potential exists across the membrane, a permeable ion travels through membrane with respect to this potential until electrochemical equilibrium is established $\left(\Delta \mu_{H^{+}}=0\right) \cdot \mathrm{pH}$ gradient has been reported to have a more dominant effect than the difference in membrane potential $[28,31]$.

Biologically, most cytoplasm membrane is built basically as a bilayer of lipids which has low permeability of protons and most nutrients. The membrane contains channel protein which is a special arrangement of amino acids embedded in the cell membrane to allow the influx of protons and nutrients and extrusion of waste products [32]. Hence, the permeability of proton through membrane and membrane channels may limit the flow 
of proton through bacterial membrane. Previous literature reported and summarized the change of the membrane composition of bacteria when they encounter low $\mathrm{pH}$ condition in E. coli and Streptococcus mutans [33,34]. Recently, Hang Yu et al. [35] reported D. vulgaris when exposed to acidic conditions, had the largest differently expressed gene for acidrelated in the Gene Ontology (GO) term "GO0016021- integral component of membrane". The study revealed the adjustment in the cell membrane composition under acid stress and this change was the main factor that strengthen the adaptation of bacteria to low extracellular $\mathrm{pH}$. Modifying the membrane channel size also contributes to the response of bacteria to acidic conditions. Amaro et al. [36] reported that Acidithiobacillus ferrooxidans showed the gene expression to attempt to modify the channel by forming a large L3 loop as their response to acidic condition. This resulted in decreasing the influx of proton through membrane. However, there was no report discussing modification of the channel size of the membrane of SRB regarding to acid stress.

\section{Increase in Pumping Proton Out of the Cytoplasm}

The proton pumps are directed outwardly all over the external $\mathrm{pH}$ range; accordingly, the potential is always negative inside [37]. The enhancement of increasing outflux of proton from cytoplasm is essential for maintaining $\mathrm{pH}$ homeostasis with low extracellular $\mathrm{pH}$. Excess proton in cytoplasm may inhibit ATP hydrolysis and photochemical reactions [38]. $\mathrm{F}_{1} \mathrm{~F}_{0}$-ATPase have ability to hydrolyse ATP to promote outflux of protons outside cells, hence, this enzyme can be considered as effective maintenance of $\mathrm{pH}$ homeostasis to prevent internal acidification. Enterococci was shown to have cytoplasmic $\mathrm{pH}$ regulated by $\mathrm{F}_{1} \mathrm{~F}_{0}$-ATPase under acidic conditions [39]. The same finding was found in E. coli [40]. When the pmf decreases below a threshold level as the extracellular $\mathrm{pH}$ decrease, $\mathrm{F}_{1} \mathrm{~F}_{0}$-ATPase may act as a proton exporter [41]. It was reported this reaction of $\mathrm{F}_{1} \mathrm{~F}_{0}$-ATPase might be a result of reorientation of the $\varepsilon$ subunit which is known as ATPase endogenous inhibitor, toward $F_{0}$ and away from the $\beta$ subunit of $F_{1}$. The rearrangement consequently may enable the $F_{1}$ part to hydrolyse ATP and export protons. The atp operon contains 8 genes encoding subunits of $\mathrm{F}_{1} \mathrm{~F}_{0}$-ATPase. Previous research in E. coli showed that in low $\mathrm{pH}$ conditions, $\operatorname{atp} A, B, C, D, E, F, G$ and $I$ expression was decreased [42]. This gene expression correlated negatively in $\mathrm{F}_{1} \mathrm{~F}_{0}$-ATPase under acidic conditions. However, D. vulgaris was shown to have atp $A, B$ and $H$ expression upregulated [35] which have positive effect on $\mathrm{F}_{1} \mathrm{~F}_{0}$-ATPase function. This reaction supported bacterial survival and growth at low environmental $\mathrm{pH}$.

\section{Increase in Proton Consumption}

Besides controlling the influx and outflux of proton flow, bacteria promote a strategy to combat acid stress by increase the consumption of proton. It has been reported that some bacteria develop enzymes to produce alkaline products in order to neutralize excessive cytoplasmic protons, e.g., the ammonium-forming enzymes in urease systems such as Helicobacter pylori, Bacillus cereus [43,44]. Amino acid synthesized by bacteria also was found to help maintaining cytoplasm $\mathrm{pH}$ homeostasis by increasing intracellular $\mathrm{pH}$ during metabolism [45]. E. coli [46] and Listeria monocytogenes [47] activates different acid resistance systems under acid conditions, where cells attempt to alkalinize cytoplasmic $\mathrm{pH}$, and require the presence of amino acids during acid challenge. These systems are known as the glutamate decarboxylase system (gadABC operon) [48], the arginine decarboxylase system (adiA) and lysine decarboxylase (CadA) [49]. D. vulgaris was reported to have gene expression of synthesis of amino acid under acid stress [35], however it is still unclear if this amino acid metabolism involved in neutralising cytoplasmic $\mathrm{pH}$.

\subsubsection{Regulation of Protein Synthesis}

The regulation of protein synthesis is essential for bacteria to survive under acidic stress as it is a common mechanism that supports the bacterial acid stress response [50]. The protection or repair of macromolecules such as DNA and proteins are promoted by specific proteins which are usually generated in acidic environments. Various chaperone 
proteins which play an important role in the synthesis, transport, folding, and degradation of proteins have been considered as significant acid tolerance factors [51]. This was found in periplasm of different Gram-negative bacteria which possess HdeA and HdeB, which are two periplasmic chaperones [52]. HdeB has been recognized as the protection of enteric bacteria from gastric acid damage and HdeA is the protection of bacteria against acid stress due to the accumulation of organic acids [52]. Even though this mechanism is common in various type of bacteria, especially Gram negative bacteria [53], there is no report about the mechanism on SRB. Alternatively, it was found in D. vulgaris under acidic stress, six genes in GO term "GO:0005840-ribosome", including $r p l C$, rps Q, rpsO, rpsJ and yfiA was enriched [35]. The bacteria have developed different mechanisms in order to relieve the stress caused by antibiotic inhibition such as fusidic acid [54]. Previous study has shown that protein factor-related mechanisms have also been found to reduce antibiotic stress by binding to the ribosome, such as fusidic acid resistance in staphylococci through the action of the FusB-like proteins [55].

\subsubsection{Change in Metabolic Pathway}

SRB was found to have flexible metabolic pathway to survive and grow in extreme environments. In acidic environments, gene expression that related to sulphate reduction of D. vulgaris, e.g., DVU0499 and sat was downregulated as decreasing $\mathrm{pH}$ [35]. DVU0499 is a hypothetical protein that is predicted to carry out sulphate reduction of D. vulgaris [35]. ATP sulfurylase which is encoded by sat gene plays an essential role in converting free sulphate into APS in dissimilatory sulphate reduction [56]. The downregulation of these gene expressions indicated that the sulphate reduction of D. vulgaris was limited. Hence, bacteria need to adjust their metabolic strategy to reduce energy consumption and increase metabolic efficiency to enhance their survival and growth [35]. Indeed, sulphate reduction is not the only pathway to obtain energy of SRB as in sulphate-free environments, SRB can develop functions to perform sulphate-free metabolism which is described in previous section. Noticeably, D. vulgaris showed gene expression of DVU1556, which is related to methyltransferase, was upregulated. Methyltransferases are enzymes which transfer methyl groups and result in methylation. Methylation was reported to initially evolved in protein activities in microbes to adapt to metabolic milieu [57,58]. Hence, methylation could possibly play an essential role in adapting to extreme environments of SRB. Additionally, the gene expression which is related to energy metabolism, e.g., atp $A, B, H$ was upregulated which suggests that the increasing in metabolic efficiency to enhance survival and growth at low $\mathrm{pH}$ conditions [35]. These expressions of genes in acidic condition were similar to electron donor response of $D$. vulgaris.

\subsubsection{Other Factors Support Survival and Growth of SRB}

In addition to SRB's own strategy to acid stress, the existence of microniches can attribute to SRB acid tolerance. Microniches are small sites which are different from the bulk environment. Fortin et al. reported the presence of microniches of higher $\mathrm{pH}$ around bacteria in an acid mine tailing environment [59]. Microniches can only be sustained thermodynamically by an active energy consumption process. If the $\mathrm{pH}$ inside microniches need to maintained at neutral $\mathrm{pH}$ in acidic bulk environment, bacteria need to have proton consuming process [25]. Sulphate reduction is a proton consuming process, thus SRB can maintain their microniches at elevated $\mathrm{pH}$. Additionally, in natural environment, SRB can be protected by the protective layer caused by the entrapment of precipitation of sulphide and iron/other metals in the matrix of biofilm. This precipitation layer can act as diffusion barrier to proton from environment [59-61].

Another factor that can be taken into account for bacterial survival and growth is the change in environmental $\mathrm{pH}$. As sulphate reduction is a proton consuming process, thus the concentration of proton in environment decreases which generates neutral/alkaline $\mathrm{pH}$ of the environment [62] which is suitable for optimising bacterial growth. The growth of 
D. vulgaris was arrested at $\mathrm{pH} 4$, however regrew after a few days when the bulk solution $\mathrm{pH}$ increases [17].

The application of this change in environmental $\mathrm{pH}$ has been used in bioremediation where to neutralize environmental $\mathrm{pH}$. As $\mathrm{pH}$ increases, this results in precipitation of metals which is used in heavy metal removal $[14,51,63]$.

\subsection{Sulphate Reduction at Low $\mathrm{pH}$}

Sulphate reduction rate at lower $\mathrm{pH}$ are influenced by four primary factors, including concentration of $\mathrm{H}^{+}$, organic acid, sulphide concentration and metals. The reduction of sulphate reaction can be written as reaction (2)-(5) [64].

$$
\begin{aligned}
\mathrm{SO}_{4}^{2-}+8 \mathrm{H}^{+}+8 e^{-} & \rightarrow \mathrm{S}^{2-}+4 \mathrm{H}_{2} \mathrm{O} \\
\mathrm{SO}_{4}^{2-}+9 \mathrm{H}^{+}+8 e^{-} & \rightarrow \mathrm{HS}^{-}+4 \mathrm{H}_{2} \mathrm{O} \\
\mathrm{SO}_{4}^{2-}+10 \mathrm{H}^{+}+8 e^{-} & \rightarrow \mathrm{H}_{2} \mathrm{~S}+4 \mathrm{H}_{2} \mathrm{O} \\
\mathrm{HS}^{-}+\mathrm{H}^{+} & \rightarrow \mathrm{H}_{2} \mathrm{~S}
\end{aligned}
$$

\subsubsection{Proton Concentration}

Sulphate reduction (reactions 2-5) is a proton consuming process; thus, the Gibbs free energy is more negative with decreasing $\mathrm{pH}$ [65]. This results in more energy release from the reactions at low $\mathrm{pH}$. For example, assuming concentrations of $1 \mathrm{~mol} / \mathrm{L}$ for all reactants, except $\mathrm{H}^{+}$, the $\Delta \mathrm{G}$ of hydrogenotrophic sulphate reduction $\left(\mathrm{H}_{2}\right.$ as electron donor) is $-198 \mathrm{~kJ} / \mathrm{mol}$ at $\mathrm{pH} 3$ compared with $-175 \mathrm{~kJ} / \mathrm{mol}$ at $\mathrm{pH} 5$ [25]. The extra energy gained can be consumed by pumping protons out of the cytoplasm to maintain a suitable cytoplasmic $\mathrm{pH}$ for bacteria to survive and grow. The sulphate reduction rate increases as a consequence. The maximum biogenic sulphide production of $D$. vulgaris at $\mathrm{pH} 5$ was $60 \%$ higher than at $\mathrm{pH} 7.4$ [17]. Similar findings were reported for sulphate reduction rate of $\mathrm{SRB}$ in different zones of venting sediments (Milos Island, Greece) at pH 5 and 6 [66]. The sulphate reduction rate at $\mathrm{pH} 4$ was close to zero [66] which indicates the limit of bacterial growth. In this case, SRB may have lost energy to pump protons out of the cells and lag phase in growth occurred when they change their system to respond to low $\mathrm{pH}$ conditions.

\subsubsection{Organic Acid}

The presence of organic acids at low $\mathrm{pH}$ can inhibit sulphate reduction by bacteria and may inhibit growth. Sulphate reduction by SRB in a reactor decreased with increasing lactate concentration [19]. Reis et al. [67] reported that when the $\mathrm{pH}$ is between 5.8 and 7, half of a mixed culture of SRB was inhibited by the presence of $0.9 \mathrm{mM}$ acetic acid.

\subsubsection{Sulphide Concentration}

Biogenic sulphide produced by SRB can be in the form of sulphide ions $\left(\mathrm{S}^{2-} / \mathrm{HS}^{-}\right)$or gas $\left(\mathrm{H}_{2} \mathrm{~S}\right)$ depending on $\mathrm{pH}$. At near neutral $\mathrm{pH}$, sulphide ions are favoured. As the $\mathrm{pH}$ decreases, the concentration of sulphide ions decreases and $\mathrm{H}_{2} \mathrm{~S}$ gas formation increases. Sulphide is toxic to SRB as it causes the precipitation of essential trace metals which are necessary cofactors for enzymes, and it reacts with functional groups of electron carrier systems, amino acids and metabolic coenzymes [68]. Below pH 5, most biogenic sulphide is produced as $\mathrm{H}_{2} \mathrm{~S}$ which is the most toxic form of sulphide [69]. Hydrogen sulphide is a highly permeable compound, entering cells through the cell membrane where it denatures proteins by acting as a cross-linking agent between the polypeptide chains and interfering with the metabolic coenzymes through sulphide bond formation [69]. Sulphate reduction can be inhibited by $50 \%$ in an environment containing $2-15 \mathrm{mM}^{\circ} \mathrm{H}_{2} \mathrm{~S}$ [25]. 


\subsubsection{Metals}

Metal ions can react with biogenic sulphide to form metal sulphides. This is the basis for heavy metal removal in bioremediation. However, metal sulphides can also be toxic to microorganisms. A previous study showed the inhibition of SRB activity is due to prevention of access of reactants to bacteria cells by metal sulphide [63] due to the precipitation of metal ions with reactants.

\section{SRB Activities in Alkaline Environment}

Habitats with high $\mathrm{pH}$ environment enclose alkaline ground water, soda lakes ( $\mathrm{pH}$ 8.5-10) [70], hyper alkaline water $(\mathrm{pH}>12)$ [71]. Previous literature reported the existence of alkaliphilic SRB in such high $\mathrm{pH}$ conditions $[10,13]$. The survival and growth of D. vulgaris (ATCC 7757) [18], non-alkaliphilic sulphate-reducing bacterial (SRB) consortium [72] in these conditions was discovered. The changes in gene expression of $D$. vulgaris can be seen in Figure 2.

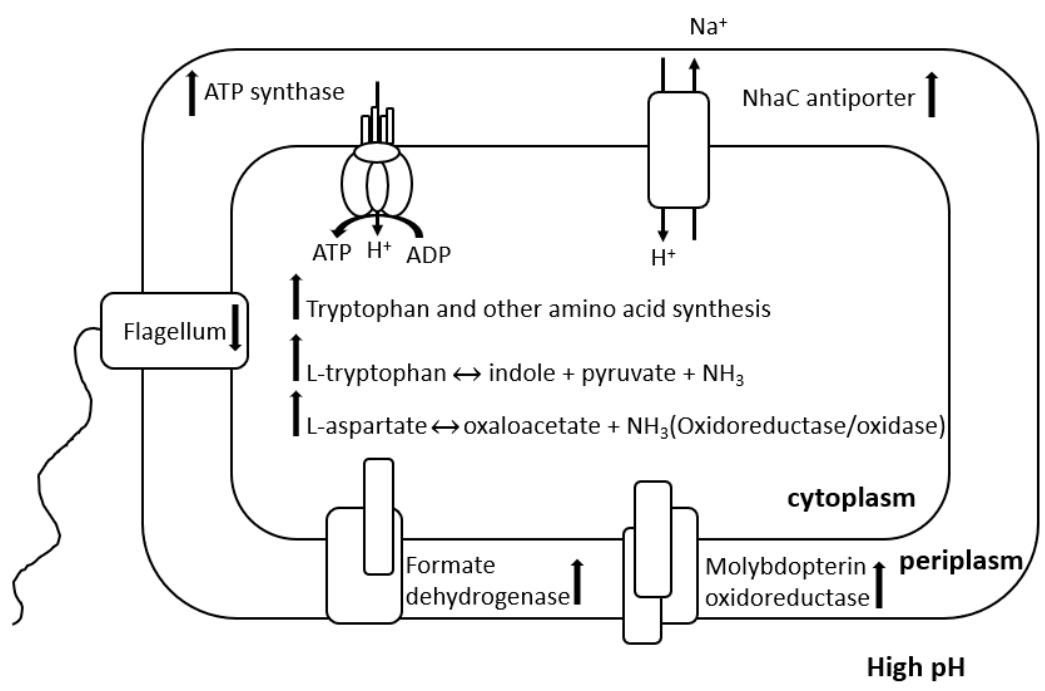

Figure 2. Theoretical model of response of D. vulgaris to alkaline environment, the $\uparrow$ indicates the increase, $\downarrow$ indicates the decrease in the corresponding of gene expression [73].

\subsection{Response of SRB to Alkaline Environment}

Several studies reported the alkaline stress of bacteria was mainly due to alkalinisation of the cytoplasm, reduced membrane potential and damaged proteins and cell envelope [74,75]. In order to be able to survive and grow in such extreme $\mathrm{pH}$ condition, SRB were found to develop adaptive strategies, including: $\mathrm{pH}$ homeostasis, cell membrane modification, increase in metabolic production and change in metabolic pathways [73].

\subsection{1. $\mathrm{pH}$ Homeostasis}

High $\mathrm{pH}$ environments have been found to cause in the depletion of proton in bacteria cytoplasm. One cell of E. coli can contain 7.2 mole proton at $\mathrm{pH} 8$ and decrease to less than 1 mole proton when environmental $\mathrm{pH}$ increase to 9 [76]. At high $\mathrm{pH}$ environment, the driving force of proton flow ( $\mathrm{pmf}$ ) is lowered because bacteria need to sustain the $\mathrm{pH}$ in the cytoplasm, which consequently has an energetically negative effect in $\mathrm{pH}$ gradient [77]. This results in dramatic decrease in ATP synthesis in bacteria metabolism. In contraction to acid stress, bacteria under alkaline stress respond increase capture and retention of protons for ATP synthesis which can be carried out by ATP synthase and antiporter cation/proton. Besides, SRB were found to regulate cell membrane and increase amino acid synthesis to maintain $\mathrm{pH}$ homeostasis [73].

ATP synthase in bacteria has two domain including: $F_{1}$ contains three catalytic $\alpha$ and $\beta$ subunit pairs and single $\gamma, \delta$, and $\varepsilon$ subunits; $\mathrm{F}_{0}$ contains a single $a$-subunit, two 
$b$-subunits and multiple $c$-subunits which present different stoichiometric ratios per complex in the synthase [77]. It is common in bacteria that ATP synthases are coupled to an electrochemical gradient of protons $(\mathrm{pmf})[78,79] . \mathrm{F}_{1} \mathrm{~F}_{0}$-ATPase are also energized by an electrochemical gradient of cation which is generated by cation pumping protein complexes in the membrane. The most common cations found were $\mathrm{Na}^{+}, \mathrm{Li}^{+}$and $\mathrm{K}^{+}$. The capacity of neutralophilic as well as alkaliphilic bacteria for maintaining a cytoplasmic $\mathrm{pH}$ below the external $\mathrm{pH}$, depends heavily upon electrogenic $\mathrm{Na}^{+}\left(\mathrm{Li}^{+}\right)\left(\mathrm{K}^{+}\right) / \mathrm{H}^{+}$antiporters. Sergeyet al. [73] reported that when $D$. vulgaris was exposed to environment with $\mathrm{pH}$ of 10 , gene expression related to ATP synthase including DVU0774-0780 $\left(F_{1} \varepsilon, F_{1} \beta, F_{1} \gamma, F_{1} \alpha, F_{1} \delta\right.$, $F_{0} B$ and $F_{0} B$, respectively) and antiporter $\mathrm{Na}^{+} / \mathrm{H}^{+} \mathrm{NhaC}($ nhaC) including $D V U 3108$ were upregulated. This indicated that $D$. vulgaris used mainly $\mathrm{Na}^{+} / \mathrm{H}^{+}$antiporter for regulating the intracellular $\mathrm{pH}$ homeostasis. Hence, both the electrochemical gradients of $\mathrm{Na}^{+}$, or sodium motive force (smf) and pmf are essential for energizing ATP synthesis.

Electrogenicity of the antiporter can be readily explained by assuming a certain stoichiometry between the $\mathrm{Na}^{+}$and protons and kinetics of the exchange, the $\mathrm{K}_{\mathrm{D}}$ of substrate binding, positive and negative effectors of the activity, structure-function relationships and the reaction mechanism $[30,77,80]$. An electrogenic $\mathrm{Na}^{+} / \mathrm{H}^{+}$antiporter when exposed to extreme environments will be driven by the $\Delta \mathrm{pH}$ initially formed by the primary proton pumps: $\mathrm{Na}^{+}$will be extruded and $\mathrm{H}^{+}$will be returned to the cell. The antiporters take up external $\mathrm{H}^{+}$in exchange for $\mathrm{Na}^{+}$from the cytoplasm, with a ratio of proton per sodium ion more than 1 . Therefore, the $\Delta \Psi$ (negative inside relative to the outside) drives the inward $\mathrm{H}^{+}$movement and makes it possible to acidify the cytoplasm relative to the bulk medium [30].

\subsubsection{Cell Membrane Modification}

Membrane integrity function was reported to be disturbed by high environmental $\mathrm{pH}$ [81]. The modification of cell wall properties has been reported in different bacteria exposed to extreme conditions [82-84]. D. vulgaris was shown to have changes in gene expression which are related to cell wall and membrane biogenesis [73]. Gene expression of DVU1446 which encoded lipopolysaccharide (LPS) heptosyltransferase was found to be upregulated. This gene was reported to be associated with inner core region of the outer membrane macromolecule lipopolysaccharide biosynthesis [73]. Additionally, DVU2367, DVU2368 (fabZ gene in E. coli), DVU2369 and DVU2370 gene expressions which related to cell envelope structure were shown highly regulated in D. vulgaris. DVU2367 and DVU2369 are associated with the outer membrane macromolecule lipopolysaccharide biosynthesis, DVU2368 involved in fatty acid biosynthesis and DVU2370 encoded outer membrane protein $\mathrm{OmpH}$ and is a part of the cell wall peptidoglycan biosynthetic pathway. However, there was downregulation of some genes related to cell wall biosynthesis as environmental $\mathrm{pH}$ increase in $D$. vulgaris including: $D V 2569$ for peptidyl-prolyl cis-trans isomerase, DVU1849 for L-isoaspartate O-methyltransferase and DVU1873 for peptidylprolyl cis-trans isomerase. The upregulation and down regulation of gene expressions which related to overall cell envelope could indicate the modification of the cell envelope by $D$. vulgaris in order to be able to survive and grow to alkaline environment. However, further studies are needed for studying specific change in cell surface properties.

\subsubsection{Increase in Metabolic Production Change in Metabolic Pathway}

Previous literature reported the consumption of amino acid can lead to the protonation of cytoplasm to minimize the alkaline stress of E. coli [85], Lactobacillus plantarum [86]. Several enzymes associated with amino acid synthesis were induced when bacteria exposed to alkaline environment. In E. coli, these enzymes include: enzyme tryptophan deaminase (TnaA) which produces deaminases resulting in generating acid that is adaptive to alkaline challenge [85]. Enzyme o-acetylserine sulfhydrylase A (CysK), which generates $\mathrm{NH}_{3}$ and acids was shown to be expressed at high level in alkaline conditions [76]. In D. vulgaris, gene expressions associated with amino acid were reported to be moderately upregulated [73]. 
Similar to E. coli, gene expressions of DVU0470 and DVU0471 encoded tryptophan synthase subunits $\beta$ and $\alpha$ related to tryptophan deaminase were shown to be upregulated. Additionally, there were increases in gene expressions of biosynthesis and transport of amino acids, including: gene expression for cysteine synthase A (DVU0663) which is considered a key enzyme in producing the amino acid cysteine [87]; dihydrodipicolinate reductase (DVU1609) which catalyses the second step of lysine-a type of amino acid biosynthesis; isopropylmalate dehydratase (DVU2982, 2983) and isopropylmalate synthase (DVU2981) which participates in biosynthesis of L-leucine and pyruvate metabolism; and homoserine dehydrogenase (DVU0890) which catalyses the third step in the aspartate pathway and an intermediate in the biosynthesis of threonine, isoleucine, and methionine. This indicates the employment of multicomponent of amino acid metabolism under alkaline stress.

In addition to increase in amino acid synthesis, SRB were found to change their metabolic pathways to adapt to the extreme environments. Genes in $D$. vulgaris related in some energy production and central metabolic pathways were shown to be downregulated, including a decrease in lactate oxidation [73]. Besides, there were increases in gene expressions which related to energy generation and electron transfer reactions under alkaline stress. Genes related to molybdopterin oxidoreductase include molybdopterin oxidoreductase (DVU0692), respiratory nitrate reductase (DVU0693), molybdopterin oxidoreductase and molybdopterin-binding subunit (DVU0694) was notably upregulated. These genes were similar to molybdopterin oxidoreductase (mopA, B, C, D) which were found in Desulfovibrio desulfuricans $\mathrm{G} 20$. These genes were shown to be involved in transferring electrons for sulphate reduction in cytoplasm [88]. Genes expression of formate dehydrogenase (DVU0587, 0588, 2481, 2482), thiosulphate reductase (DVU0179), cytoplasmic Coo hydrogenase (DVU2286-2291) and periplasmic (NiFe) hydrogenase (D2526) which are associated in transferring electrons were shown upregulated [73]. Due to the inhibition of lactate consumption and acetate production, the increase in these genes indicates the redirection of electron flow to sustain the redox of cytoplasm, thus controlling proton intake by pmf.

\subsubsection{Other Changes in Bacteria and Environment}

Besides, the motility of the D. vulgaris cell was shown to be restrained as the expression of flagellar genes was decreased. This indicated that under alkaline stress, bacteria tend to be involved in response of the cell to environmental $\mathrm{pH}$ rather than motility. This response of D. vulgaris was similar to E. coli [42].

Furthermore, several researchers reported the change in initial elevated environmental $\mathrm{pH}$ to around neutral $\mathrm{pH}$ during the survival and growth of neutrophilic bacteria. The decrease in environmental $\mathrm{pH}$ to around neutral can be beneficial for bacteria to growth. An anaerobic bacteria Lactobacillus plantarum produces lactic acid and, hence, lowers the environmental $\mathrm{pH}$ to a preferable $\mathrm{pH}$ condition for their growth [89]. Vibrio tapetis which cause brown ring disease was reported to decrease the environmental $\mathrm{pH}$ to around 7.5 for their metabolism [90]. The decrease in environmental $\mathrm{pH}$ was also observed in SRB. D. vulgaris was reported to change from alkaline $\mathrm{pH}$ to around 7.4 after 28 days of immersion [18]. The possible explanation is that $D$. vulgaris can modulate environmental $\mathrm{pH}$ by $\mathrm{pH}$ homeostasis-neutralizing activities during their survival and growth. Additionally, the metabolic products of sulphate reduction $\mathrm{H}_{2} \mathrm{~S}$ is more dissolved in the alkaline environment which can release proton to environment and contribute to the decrease in environmental $\mathrm{pH}$ [18]. In fact, the growth of $D$. vulgaris was reported to be arrested at a $\mathrm{pH}$ of $10[18,73]$, however they resume growth after few days when environmental $\mathrm{pH}$ decreases [18]. The drop of environmental $\mathrm{pH}$ can be partly caused by SRB metabolic activities in high $\mathrm{pH}$ environment which were mentioned in Sections 4.1.1-4.1.3. Additionally, the reaction of bacterial metabolites/cation (such as cation released from corroded materials) with hydroxide ion $\mathrm{OH}^{-}$from the environment, which caused a reduction in the concentration of hydroxide ions [18]. Finally, the metabolic activities of other bacteria shared the same environment can cause the fall in environmental $\mathrm{pH}$. The resumption of 
bacterial growth suggests that there is a phase lag of SRB for a few days when they develop the strategy to combat high $\mathrm{pH}$ environment.

Overall, the response of neutrophilic SRB to alkaline environment showed different SRB species might have different specific strategy to alkaline stress. For example, gene expression of DVU3110 related to oxidoreductase was not found in Desulfovibrio desulfuricans G20. More studies in different SRB species response to alkaline stress need to be conducted to improve the evolution of SRB in alkaline environment.

\subsection{Sulphate Reduction in Alkaline Environment}

Under alkaline environment, there are many factors that can have effect on SRB sulphate reduction, including but not limited to environmental $\mathrm{pH}$, dissolved sulphide ion, organic matter and metal/mineral precipitation.

\subsubsection{Environmental $\mathrm{pH}$}

Thermodynamically, a favourable redox reaction at a specific $\mathrm{pH}$ condition can be predicted by available energy of the redox reaction. Higher available energy enhances higher reaction rate of the redox reaction and might be higher available energy for bacteria survival and growth. Sulphate reduction (Reactions 2-5) results in the donation of electrons from hydrogen or carbon sources, e.g., lactate, acetate, propionate and methanol are oxidation reactions. Qusheng and Matthew [5] reported the available energy of sulphate reduction by the oxidation of carbon sources increases with the increase in $\mathrm{pH}$ from 7 to 14. Environmental conditions where contain high carbon sources, the overall sulphate reduction thermodynamically increases with the increase in environmental alkalinity.

\subsubsection{Dissolved Sulphide Ion}

Sulphide ion/hydrogen sulphide are metabolic sulphide products of SRB metabolism. Sulphide ion is toxic to bacteria due to its reaction with metal ions and functional groups of electron carrier systems [68], amino acid and metabolic coenzymes [25]. As the environmental $\mathrm{pH}$ increases, the concentration of $\mathrm{H}_{2} \mathrm{~S}$ declines whereas the concentration of $\mathrm{HS}^{-}$and $\mathrm{S}^{2}$ increases [5,91]. It was reported that at $\mathrm{pH}$ higher than 9 , around $99 \%$ of $\mathrm{H}_{2} \mathrm{~S}$ was dissolved in solution [91]. However, in comparison to acidic environment, biogenic sulphide produced by SRB at alkaline environment has less toxic impact on bacteria than $\mathrm{H}_{2} \mathrm{~S}$.

\subsubsection{Organic Matter}

Organic matter can be defined as biological material in the process of decaying or decomposing. For a long time, sulphate reduction rate was reported to be affected by organic matter $[92,93]$. Laboratory, field, and theoretical research indicates that the rate of bacterial sulphate reduction rate during early diagenesis relies mainly sedimentary organic matter reactivity [92] as bacteria use carbon source as electron donor. The solubility of organic matter resulted in significant increases as $\mathrm{pH}$ is raised by addition of $\mathrm{KOH} / \mathrm{Ca}(\mathrm{OH})_{2}[94,95]$ thus, sulphate reduction can be encouraged as environmental $\mathrm{pH}$ increases.

\subsubsection{Metal/Mineral Precipitation}

In alkaline environment, the presence of high concentration of $\mathrm{OH}^{-}$, biogenic sulphide $\mathrm{S}^{2-}$ and carbonate $\mathrm{CO}_{3}{ }^{2-}$ can result in metal/mineral precipitation. Carbonate can be produced by SRB metabolism as SRB reduces carbon sources to $\mathrm{CO}_{2}$. As environmental $\mathrm{pH}$ increases, $\mathrm{CO}_{2}$ converts to $\mathrm{HCO}_{3}{ }^{-}$and $\mathrm{CO}_{3}{ }^{2-}$ while $\mathrm{CO}_{3}{ }^{2-}$ is more dominant at high $\mathrm{pH}$. The increase in such anion concentrations in alkaline environment can cause high precipitation of metal/mineral. The precipitation product might act as barriers to prevent the access of reactants to bacteria cell, hence results in the inhibition of SRB activities [63]. However, it can be beneficial for bacteria as the precipitation of toxic metal ions. Additionally, the precipitation products can stand in the matrix with bacteria biofilm to prevent bacteria the effect of high $\mathrm{pH}$ environment [25]. 


\section{Microbial Corrosion by SRB}

SRB has been reported to be a dominant species attributed to MIC. The bacteria mediate between the anaerobic reduction of $\mathrm{SO}_{4}{ }^{2-}$ as electron acceptor to produce $\mathrm{S}$ and /or $\mathrm{H}_{2} \mathrm{~S}$ via half-cell electrode reactions (6)-(8) and overall reaction (9) and (10) [96]. The anodic reaction is the oxidation of metals such as $\mathrm{Fe}$ to $\mathrm{Fe}^{2+}$ and the carbon source such as lactate. The sulphides react with the metal ions and form metal sulphides which precipitate on the metal surface around the SRB and mixed with the biofilm [97]. Metal ions can also precipitate with carbonate to form metal carbonate, reaction (10).

$$
\begin{gathered}
\mathrm{Fe}^{0} \rightarrow \mathrm{Fe}^{2+}+2 e^{-} \\
\mathrm{CH}_{3} \mathrm{CHOHCOO}^{-}+\mathrm{H}_{2} \mathrm{O} \rightarrow \mathrm{CH}_{3} \mathrm{COO}^{-}+\mathrm{CO}_{2}+4 \mathrm{H}^{+}+4 e^{-} \\
4 \mathrm{Fe}+\mathrm{SO}_{4}^{2-}+8 \mathrm{H}^{+} \rightarrow \mathrm{FeS}+3 \mathrm{Fe}^{2+}+4 \mathrm{H}_{2} \mathrm{O} \\
2 \mathrm{CH}_{3} \mathrm{CHOHCOO}^{-}+\mathrm{SO}_{4}^{2-} \rightarrow 2 \mathrm{CH}_{3} \mathrm{COO}^{-}+2 \mathrm{HCO}_{3}^{-}+\mathrm{H}_{2} \mathrm{~S} \\
\mathrm{Fe}^{2+}+\mathrm{HCO}_{3}^{-} \rightarrow \mathrm{FeCO}_{3}+\mathrm{H}^{+}
\end{gathered}
$$

SRB cause MIC not only in neutral environment but also in acidic and alkaline environments and on different type of metal materials, e.g., mild steel, stainless steel, duplex stainless steel, hyper duplex stainless steel, copper and aluminium. Corrosion rate of carbon steel (CS) and duplex stainless steel (DSS) caused by SRB in different $\mathrm{pH}$ in stagnant condition are shown in Table 1. As can be seen from Table 1, generally, corrosion rate of materials was high at lower $\mathrm{pH}$ environment and high $\mathrm{pH}$ environment. The possible explanation is that because of the contribution of microorganism activities and environment factors, such as concentration of protons, hydroxyl, and other anions such as chlorides.

\subsection{Microbial Corrosion in Acidic Environment}

\subsubsection{Environment Factors}

Protons contributing to corrosion, also called acid corrosion, can occur in various metal materials such as carbon steel, copper, zinc and aluminium [98]. Carbon steel was reported to be highly prone to acid corrosion as $\mathrm{H}^{+}$ions react with electrons in cathodes [99-101], thus the corrosion rate of carbon steel at low $\mathrm{pH}$ is high [102]. Stainless steel is generally resistant to acid corrosion because of the formation of passive film [103]. However, proton concentrations coupled to the presence of halides such as chloride, stainless steel was susceptible to localized corrosion because of the destruction of the passive film leading to pitting corrosion.

\subsubsection{Microbial Activities}

As addressed above about sulphate reduction activities of SRB, in acidic environment, sulphate reduction gains more available energy than at neutral $\mathrm{pH}$. The lower the $\mathrm{pH}$, the more energetically advantageous, the higher the sulphide produced. Biogenic sulphide ions/hydrogen sulphides are reported to be detrimental to corrosion resistance of steel as they react readily with anodic ferrous ions to cause the precipitation of iron sulphides. It has been proposed that corrosion proceeds through the depolarisation of the cathodic area by adsorption of the polarising $\mathrm{H}_{2}$ into the crystal lattice of the iron sulphide species which causes sulphide stress cracking (SSC), or the establishment of an aggressive galvanic cell of iron/iron sulphide [104], both of which result in the acceleration of corrosion. Consequently, microbial corrosion caused by SRB was higher at low $\mathrm{pH}$ environments. Additionally, higher reduction rate of sulphate requires higher oxidation of carbon sources and metal which are the main source of electron donor [64]. As and when bacteria attach to a material surface, the matrix of formation of biofilm on metals and the precipitation of metal sulphide/metal carbonate can prevent the diffusion of carbon source like lactate source from environment [64]. This could consequently increase the dissolution rate of 
metals. Overall, corrosion of metals was accelerated at low $\mathrm{pH}$, which was proved by laboratory experiment in both carbon steels and duplex stainless steels.

On the other hand, the layer of the biofilm and metal sulphide/carbonate precipitation can be advantageous for corrosion resistance of material under acidic environments as they prevent the diffusion of proton and chloride from environment [105]. Indeed, the protection ability of biofilm as a barrier for metal has been reported in several types of bacteria in extreme $\mathrm{pH}$ environments [106-108]. Chongdar et al. [109] addressed that aerobic Pseudomonas cichorii was able to inhibit the corrosion of mild steel in corrosive phosphatebuffered basal salt solution (BSS). Analysis of surface film using Fourier transform infrared (FTIR) spectroscopy revealed that formation of an iron oxide/iron phosphate layer within biofilm matrix may contribute to the corrosion reduction. Rongjun et al. [106] reported that a protective biofilm of Bacillus subtilis WB600 formed on aluminium alloy Al 2024 as the alloy was passive in the presence of bacteria and was prone to corrosion without the bacteria. Naguib and Mansfeld [4] studied the corrosion behaviour of Al 2024, cartridge brass, and mild steel in AS containing Shewanella ana and also revealed the protective behaviour of the biofilm [107].

The experimental results in $\mathrm{pH} 4$ environment from ref. [17] are interesting. The growth of bacteria was arrested for the first 5 days and resumed when the bulk $\mathrm{pH}$ increases to around 4.6. Corrosion rate was found to slow down when the bacteria growth due to the presence of biofilm along with the precipitation of corrosion products. This acted as a barrier to prevent the diffusion of proton and chloride from environment.

Overall, in a very extreme corrosive environment such as low $\mathrm{pH}$ with presence of chloride, the layer where minerals and corrosion products are entrapped in the exopolymer matrix of biofilm can be advantageous for resistance of materials.

Additionally, the presence of organic compounds in the environment at low $\mathrm{pH}$ can also impact corrosion resistance of materials $[110,111]$. Acetate is the final metabolic products in the oxidation of lactate/pyruvate caused by SRB. It was reported that acetate can cause higher corrosion in materials than formate, pyruvate and lactate in the environment without the presence of SRB [111]. Additionally, authors reported that in D. desulfuricans containing environment, high amount of acetate was produced by bacteria metabolism and hence, resulted in high corrosion rate of iron coupons. The authors also suggested the higher impact of acetate produced by SRB metabolism at low $\mathrm{pH}$ on materials corrosion than biogenic sulphide.

However, when an experiment was carried out in sulphate free medium, bacteria changed their metabolic pathways to sulphate free metabolism, sulphide was not produced. Additionally, acetic acid was found to have inhibition effect on SRB metabolism as mentioned above. Hence, the comparison of impact of acetate and sulphide requires further study.

Besides, most of the studies were conducted in near stagnant conditions in a specific volume in laboratory. When SRB achieve the growth, the bulk $\mathrm{pH}$ increased consequently. Thus, the effect of proton concentration on corrosion of materials was reduced. However, these conditions cannot simulate the actual condition in nature, e.g., in waste water. Further studies in corrosion of materials in open conditions where there is a bulk environmental should be taken undertaken. 
Table 1. Corrosion rate of different materials according to different $\mathrm{pH}$ environment.

\begin{tabular}{|c|c|c|c|c|c|c|c|c|c|c|c|c|c|c|c|c|}
\hline \multirow{2}{*}{ Material Type } & \multirow{2}{*}{ SRB Species } & \multirow{2}{*}{ Solution } & \multicolumn{12}{|c|}{ Corrosion Rate at Different $\mathrm{pH}\left(10^{-3} \mathrm{~mm} /\right.$ Year $)$} & \multirow[t]{2}{*}{ Ref. } & \multirow[t]{2}{*}{ Note } \\
\hline & & & 4.0 & 5 & 5.5 & 6.0 & 6.5 & 7.0 & 7.5 & 8.0 & 8.5 & 9.0 & 9.5 & 10 & & \\
\hline DSS 2205 & D. vulgaris & Artificial sea water & 6.1 & 1.0 & - & 0.6 & - & - & 0.5 & - & - & - & - & - & {$[17]$} & $\begin{array}{l}\text { Calculated from } \\
\text { current density }\end{array}$ \\
\hline DSS 2205 & D. vulgaris & Artificial sea water & - & - & - & - & - & - & 1.9 & 2.6 & - & 10.1 & - & 3.3 & {$[18]$} & $\begin{array}{l}\text { Calculated from } \\
\text { current density }\end{array}$ \\
\hline CS API 5L X70 & D. vulgaris & Modified Baar's medium & - & - & 13.1 & 8.5 & 6.8 & 12 & 7.5 & 9.4 & 11.4 & 13.1 & 14 & - & [102] & - \\
\hline CS API 5L X70 & Not identified & Artificial sea mud extract & - & - & - & 18.4 & - & - & - & 26.8 & - & - & - & 21.3 & {$[112]$} & $\begin{array}{l}\text { Calculated from } \\
\text { current density }\end{array}$ \\
\hline
\end{tabular}




\subsection{Microbial Corrosion in Alkaline Environment}

\subsubsection{Environmental Factor}

Under alkaline environments, steels in general were found to increase their corrosion resistance and decrease the overall corrosion rate [113-119] due to the presence of protective films. However, in alkaline solutions with the presence of alkali cations such as $\mathrm{K}^{+}, \mathrm{Li}^{+}$, protective films were reported to be disrupted [120,121].

\subsubsection{Microbial Activities}

As addressed in Section 4.2, sulphate reduction gains an energetic advantage at high $\mathrm{pH}$, thus the reduction of sulphate is favourable and requires high electron donor consequently. The precipitation of metal sulphide/metal carbonate as corrosion products can act as a barrier to prevent the diffusion of carbon sources from environment to bacteria. This results in high oxidation of metals which is similar to acidic conditions in that bacteria might be under carbon starvation by the barrier of corrosion products, hence accelerates corrosion process of materials.

The production of biogenic sulphide is mainly sulphide ions in alkaline environment with the dissolution of hydrogen sulphide. Sulphide ion was reported to account for accelerating corrosion as sulphide is aggressive to passive film on stainless steel [122-124]. Sulphide causes the susceptibility of materials to corrosion by various ways, including cathodic depolarisation [125] and changes to the local $\mathrm{pH}$ upon hydrolysis reactions of dissolved metal ions and initiates pitting [126], supporting active dissolution of steel [127], and increasing electron uptake through metal sulphides [128]. The increase in sulphide ion concentrations led to the increase in corrosion rate of materials. An example is in ref. [129], which was included in Table 1. The corrosion rate of carbon steel increased by $86.7 \%$ when environmental $\mathrm{pH}$ increases from 7.5 to 9.5. Duplex stainless steel was also reported to accelerate the corrosion rate from $1.9\left(\mu \mathrm{m} \mathrm{year}^{-1}\right)$ at $\mathrm{pH} 7.5$ to 10.1 ( $\mu \mathrm{m} \mathrm{year}^{-1}$ ) at $\mathrm{pH} 9$ [18]. As mentioned above, the enhancement of protective film of materials leads to the increase of corrosion resistance of materials as environmental $\mathrm{pH}$ increases. However, in the SRB-containing environment, corrosion of materials increases with the increase of $\mathrm{pH}$ due to the high production of biogenic sulphide ions.

The oxidation of carbon sources as electron donor for sulphate reduction produces carbonate under alkaline conditions as addressed in Section 4.2. Carbonate has been reported to cause scale in equipment such as heat exchanger, wellbore tubulars and components and transportation pipe lines [130,131]. The scale of carbonate precipitation such as iron carbonate was reported to act as a protective layer to prevent corrosion of materials [132-134]. Previous literature reported the application of calcium carbonate on corrosion prevention of materials [132,135]. However, the concentration of calcium should be taken into account as high concentrations of $\mathrm{Ca}^{2+}$ could lead to the change of corrosion products from protective iron carbonate to non-protective calcium carbonate, and increase the corrosion rate [136].

On the other hand, microbial corrosion of materials in alkaline environment also depends on the growth of bacteria. D. vulgaris was reported to have an arrested growth at $\mathrm{pH} 10$ solution [18]. Sulphide production was very low for the first 6 days until the environmental $\mathrm{pH}$ decreased and further bacteria growth was achieved. Thus, for the first few days, materials were protected from corrosion from the formation of protective layer and later the corrosion was accelerated by SRB metabolism.

Overall, microbial corrosion of materials was attributed by different competitive factors. Although corrosion prevention of materials from the protective hydroxide film and the formation of corrosion products layer can act as protective layer to prevent corrosion process, SRB metabolism and high sulphide concentration still cause high corrosion rate of materials. However, corrosion caused by SRB in $\mathrm{pH}$ extreme environment of non-ferrous materials, e.g., amphoteric materials such as aluminium, zinc and anti-bacteria such as copper have received less attention and require further studies. 


\section{Conclusions}

SRB have several strategies for survival and growth under extreme $\mathrm{pH}$ environments. The main responses of SRB in extreme $\mathrm{pH}$ environments are to maintain $\mathrm{pH}$ homeostasis and change their metabolic activities in order to survive and grow. Additionally, SRB have the ability to regulate environmental $\mathrm{pH}$. SRB regulate the $\mathrm{pH}$ of the environment under acidic conditions to $\mathrm{pH} 7.4$ by converting proton to $\mathrm{H}_{2} \mathrm{~S}$ which will escape as gas and by producing $\mathrm{H}_{2} \mathrm{O}$. In an alkaline environment, the $\mathrm{H}_{2} \mathrm{~S}$ produced dissolves in the environment and decreases the $\mathrm{pH}$ to 7.4. The regulation of environmental $\mathrm{pH}$ to around neutral $\mathrm{pH}$ supported the growth of SRB and had a strong influence on MIC. The corrosion of materials caused by bacteria metabolism and environmental factors was explained. The survival and growth of bacteria have a significant impact on the production of metabolic corrosive products and material corrosion.

Author Contributions: Conceptualization, T.T.T.T.; investigation, T.T.T.T.; resources, T.T.T.T.; writingoriginal draft preparation, T.T.T.T.; writing—review and editing, K.K., A.P. and S.T. All authors have read and agreed to the published version of the manuscript.

Funding: This research was supported by an Australian Research Training Program Scholarship provided through Charles Darwin University; grant number is 1578028.

Institutional Review Board Statement: Not applicable.

Informed Consent Statement: Not applicable.

Conflicts of Interest: The authors declare no conflict of interest.

\section{References}

1. Kotsyurbenko, O.R.; Chin, K.J.; Glagolev, M.V.; Stubner, S.; Simankova, M.V.; Nozhevnikova, A.N.; Conrad, R. Acetoclastic and hydrogenotrophic methane production and methanogenic populations in an acidic West-Siberian peat bog. Environ. Microbiol. 2004, 6, 1159-1173. [CrossRef]

2. Wu, Y.; Zeng, J.; Zhu, Q.; Zhang, Z.; Lin, X. pH is the primary determinant of the bacterial community structure in agricultural soils impacted by polycyclic aromatic hydrocarbon pollution. Sci. Rep. 2017, 7, 1-7. [CrossRef]

3. John, N.; Vidyalakshmi, V.; Hatha, A.M. Effect of $\mathrm{pH}$ and salinity on the production of extracellular virulence factors by Aeromonas from food sources. J. Food Sci. 2019, 84, 2250-2255. [CrossRef]

4. Leprince, F.; Quiquampoix, H. Extracellular enzyme activity in soil: Effect of $\mathrm{pH}$ and ionic strength on the interaction with montmorillonite of two acid phosphatases secreted by the ectomycorrhizal fungus Hebeloma cylindrosporum. Eur. J. Soil Sci. 1996, 47, 511-522. [CrossRef]

5. Jin, Q.; Kirk, M.F. pH as a primary control in environmental microbiology: 1. thermodynamic perspective. Front. Environ. Sci 2018, 6, 21. [CrossRef]

6. Jin, Q.; Kirk, M.F. pH as a primary control in environmental microbiology: 2. Kinetic perspective. Front. Environ. Sci 2018, 6, 101. [CrossRef]

7. Widdel, F. Microbiology and ecology of sulfate-and sulfur-reducing bacteria. In Biology of Anaerobic Microorganisms, 99th ed.; Zehnder, A.J.B., Ed.; Wiley: California, CA, USA, 1988; Volume 1, pp. 469-585.

8. Zagury, G.J.; Kulnieks, V.I.; Neculita, C.M. Characterization and reactivity assessment of organic substrates for sulphate-reducing bacteria in acid mine drainage treatment. Chemosphere 2006, 64, 944-954. [CrossRef]

9. Carlier, J.D.; Luís, A.T.; Alexandre, L.M.; Costa, M.C. Feasibility of Co-Treating Olive Mill Wastewater and Acid Mine Drainage. Mine. Water. Environ. 2020, 39, 1-22. [CrossRef]

10. Abildgaard, L.; Nielsen, M.B.; Kjeldsen, K.U.; Ingvorsen, K. Desulfovibrio alkalitolerans sp. nov., a novel alkalitolerant, sulphatereducing bacterium isolated from district heating water. Int. J. Syst. Evol. Microbiol. 2006, 56, 1019-1024. [CrossRef]

11. Zhilina, T.N.; Zavarzin, G.A. Alkaliphilic anaerobic community at pH 10. Curr. Microbiol. 1994, 29, 109-112. [CrossRef]

12. Ryzhmanova, Y.; Nepomnyashchaya, Y.; Abashina, T.; Ariskina, E.; Troshina, O.; Vainshtein, M.; Shcherbakova, V. New sulfatereducing bacteria isolated from Buryatian alkaline brackish lakes: Description of Desulfonatronum buryatense sp. nov. Extremophiles 2013, 17, 851-859. [CrossRef]

13. Sorokin, D.; Chernyh, N.; Poroshina, M. Desulfonatronobacter acetoxydans sp. nov.: A first acetate-oxidizing, extremely salt-tolerant alkaliphilic SRB from a hypersaline soda lake. Extremophiles 2015, 19, 899-907. [CrossRef]

14. Sen, A.; Johnson, B. Acidophilic sulphate-reducing bacteria: Candidates for bioremediation of acid mine drainage. In Process Metallurgy; Elsevier: Amsterdam, The Netherlands, 1999; Volume 9, pp. 709-718.

15. Johnson, D.B.; Ghauri, M.; McGinness, S. Biogeochemical cycling of iron and sulphur in leaching environments. EMS Microbiol. Rev. 1993, 11, 63-70. [CrossRef] 
16. Mori, K.; Kim, H.; Kakegawa, T.; Hanada, S. A novel lineage of sulfate-reducing microorganisms: Thermodesulfobiaceae fam. nov., Thermodesulfobium narugense, gen. nov., sp. nov., a new thermophilic isolate from a hot spring. Extremophiles 2003, 7, 283-290. [CrossRef]

17. Thuy, T.T.; Krishnan, K.; Padovan, A.; Thennadil, S. Effect of $\mathrm{pH}$ regulation by sulphate reducing bacteria on corrosion behaviour of duplex stainless steel 2205 in acidic artificial seawater. R. Soc. Open Sci. 2020, 8, 1-13.

18. Thuy, T.T.T.; Kannoorpatti, K.; Padovan, A.; Thennadil, S. Effect of Alkaline Artificial Seawater Environment on the Corrosion Behaviour of Duplex Stainless Steel 2205. Appl. Sci. 2020, 10, 5043. [CrossRef]

19. Jong, T.; Parry, D.L. Microbial sulfate reduction under sequentially acidic conditions in an upflow anaerobic packed bed bioreactor. Water. Res. 2006, 40, 2561-2571. [CrossRef] [PubMed]

20. Muyzer, G.; Stams, A. The ecology and biotechnology of sulphate-reducing bacteria. Nat. Rev. Microbiol. 2008, 6, 441-454. [CrossRef] [PubMed]

21. Carbonero, F.; Benefiel, A.C.; Alizadeh-Ghamsari, A.H.; Gaskins, H.R. Microbial pathways in colonic sulfur metabolism and links with health and disease. Front. Physiol. 2012, 3, 448. [CrossRef]

22. Plugge, C.M.; Zhang, W.; Scholten, J.; Stams, A.J. Metabolic flexibility of sulfate-reducing bacteria. Front. Microbiol. $2011,2,81$. [CrossRef]

23. Cypionka, H. Oxygen respiration by Desulfovibrio species. Annu. Rev. Microbiol. 2000, 54, 827-848. [CrossRef]

24. Bryant, M.; Campbell, L.L.; Reddy, C.; Crabill, M. Growth of Desulfovibrio in lactate or ethanol media low in sulfate in association with $\mathrm{H}_{2}$-utilizing methanogenic bacteria. Appl. Environ. Microbiol. 1977, 33, 1162-1169. [CrossRef]

25. Koschorreck, M. Microbial sulphate reduction at a low pH. FEMS Microbiol. Ecol. 2008, 64, 329-342. [CrossRef]

26. SATAKE, K.I. Microbial sulphate reduction in a volcanic acid lake having pH 1.8 to 2.0. Jpn. J. Limnnology 1977, 38, 33-35. [CrossRef]

27. Guan, F.; Zhai, X.; Duan, J.; Zhang, M.; Hou, B. Influence of sulfate-reducing bacteria on the corrosion behavior of high strength steel EQ70 under cathodic polarization. PLoS ONE 2016, 11, e0162315. [CrossRef] [PubMed]

28. Padan, E.; Zilberstein, D.; Schuldiner, S. pH homesstasis in bacteria. Biochim. Biophys. Acta. 1981, 650, 151-166. [CrossRef]

29. Booth, I.R. Regulation of cytoplasmic $\mathrm{pH}$ in bacteria. Microbiol. Rev. 1985, 49, 359. [CrossRef]

30. Padan, E.; Bibi, E.; Ito, M.; Krulwich, T.A. Alkaline pH homeostasis in bacteria: New insights. Biochim. Biophys. Acta Biomembr 2005, 1717, 67-88. [CrossRef] [PubMed]

31. Lee, S.-Y.; Kang, D.-H. Survival mechanism of Escherichia coli O157: H7 against combined treatment with acetic acid and sodium chloride. Food Microbiol. 2016, 55, 95-104. [CrossRef] [PubMed]

32. Nikaido, H. Molecular basis of bacterial outer membrane permeability revisited. Microbiol. Mol. Biol. Rev. 2003, 67, 593-656. [CrossRef] [PubMed]

33. Shukla, S.; Green, C.; Turner, J. Phosphatidylethanolamine distribution and fluidity in outer and inner membranes of the gram-negative bacterium Erwinia carotovora. Biochem. J. 1980, 188, 131-135. [CrossRef] [PubMed]

34. Boyd, D.A.; Cvitkovitch, D.G.; Bleiweis, A.S.; Kiriukhin, M.Y.; Debabov, D.V.; Neuhaus, F.C.; Hamilton, I.R. Defects in Dalanyl-lipoteichoic acid synthesis in Streptococcus mutans results in acid sensitivity. J. Bacteriol. 2000, 182, 6055-6065. [CrossRef] [PubMed]

35. Yu, H.; Jiang, Z.; Lu, Y.; Yao, X.; Han, C.; Ouyang, Y.; Wang, H.; Guo, C.; Ling, F.; Dang, Z. Transcriptome Analysis of the Acid Stress Response of Desulfovibrio vulgaris ATCC 7757. Curr. Microbiol. 2020, 77, 2702-2712. [CrossRef]

36. Amaro, A.; Chamorro, D.; Seeger, M.; Arredondo, R.; Peirano, I.; Jerez, C. Effect of external pH perturbations on in vivo protein synthesis by the acidophilic bacterium Thiobacillus ferrooxidans. J. Bacteriol. 1991, 173, 910-915. [CrossRef]

37. Kroll, R.; Booth, I. The role of potassium transport in the generation of a pH gradient in Escherichia coli. Biochem. J. 1981, 198, 691-698. [CrossRef]

38. Zilberstein, D.; Agmon, V.; Schuldiner, S.; Padan, E. The sodium/proton antiporter is part of the $\mathrm{pH}$ homeostasis mechanism in Escherichia coli. J. Biol. Chem. 1982, 257, 3687-3691. [CrossRef]

39. Kobayashi, H. A proton-translocating ATPase regulates $\mathrm{pH}$ of the bacterial cytoplasm. J. Biol. Chem. 1985, 260, 72-76. [CrossRef]

40. Sun, Y.; Fukamachi, T.; Saito, H.; Kobayashi, H. Respiration and the F 1 Fo-ATPase enhance survival under acidic conditions in Escherichia coli. PLoS ONE 2012, 7, e52577. [CrossRef]

41. Suzuki, T.; Murakami, T.; Iino, R.; Suzuki, J.; Ono, S.; Shirakihara, Y.; Yoshida, M. F0F1-ATPase/synthase is geared to the synthesis mode by conformational rearrangement of $\epsilon$ subunit in response to proton motive force and ADP/ATP balance. J. Biol. Chem. 2003, 278, 46840-46846. [CrossRef]

42. Maurer, L.M.; Yohannes, E.; Bondurant, S.S.; Radmacher, M.; Slonczewski, J.L. pH regulates genes for flagellar motility, catabolism, and oxidative stress in Escherichia coli K-12. J. Bacteriol. 2005, 187, 304-319. [CrossRef]

43. Mols, M.; Abee, T. Bacillus cereus responses to acid stress. Environ. Microbiol. 2011, 13, 2835-2843. [CrossRef]

44. Shimomura, H.; Hosoda, K.; Hayashi, S.; Yokota, K.; Hirai, Y. Phosphatidylethanolamine of Helicobacter pylori functions as a steroid-binding lipid in the assimilation of free cholesterol and $3 \beta$-hydroxl steroids into the bacterial cell membrane. J. Bacteriol. 2012, 194, 2658-2667. [CrossRef]

45. Senouci-Rezkallah, K.; Schmitt, P.; Jobin, M.P. Amino acids improve acid tolerance and internal pH maintenance in Bacillus cereus ATCC14579 strain. Food Microbiol. 2011, 28, 364-372. [CrossRef]

46. Bearson, S.; Bearson, B.; Foster, J.W. Acid stress responses in enterobacteria. FEMS Microbiol. Lett. 1997, 147, 173-180. [CrossRef] 
47. Ryan, S.; Begley, M.; Gahan, C.G.; Hill, C. Molecular characterization of the arginine deiminase system in Listeria monocytogenes: Regulation and role in acid tolerance. Environ. Microbiol. 2009, 11, 432-445. [CrossRef]

48. Hersh, B.M.; Farooq, F.T.; Barstad, D.N.; Blankenhorn, D.L.; Slonczewski, J.L. A glutamate-dependent acid resistance gene in Escherichia coli. J. Bacteriol. 1996, 178, 3978-3981. [CrossRef]

49. Lin, J.; Lee, I.S.; Frey, J.; Slonczewski, J.L.; Foster, J.W. Comparative analysis of extreme acid survival in Salmonella typhimurium, Shigella flexneri, and Escherichia coli. J. Bacteriol. 1995, 177, 4097-4104. [CrossRef]

50. Azcarate-Peril, M.A.; McAuliffe, O.; Altermann, E.; Lick, S.; Russell, W.M.; Klaenhammer, T.R. Microarray analysis of a twocomponent regulatory system involved in acid resistance and proteolytic activity in Lactobacillus acidophilus. Appl. Environ. Microbiol. 2005, 71, 5794-5804. [CrossRef]

51. Nicolaou, S.A.; Gaida, S.M.; Papoutsakis, E.T. A comparative view of metabolite and substrate stress and tolerance in microbial bioprocessing: From biofuels and chemicals, to biocatalysis and bioremediation. Metab. Eng. 2010, 12, 307-331. [CrossRef]

52. Mates, A.K.; Sayed, A.K.; Foster, J.W. Products of the Escherichia coli acid fitness island attenuate metabolite stress at extremely low $\mathrm{pH}$ and mediate a cell density-dependent acid resistance. J. Bacteriol. 2007, 189, 2759-2768. [CrossRef]

53. Guan, N.; Liu, L. Microbial response to acid stress: Mechanisms and applications. Appl. Microbiol. Biotechnol. 2020, 104, 51-65. [CrossRef]

54. Wilson, D.N. Ribosome-targeting antibiotics and mechanisms of bacterial resistance. Nat. Rev. Microbiol. 2014, 12, 35-48. [CrossRef] [PubMed]

55. Farrell, D.J.; Castanheira, M.; Chopra, I. Characterization of global patterns and the genetics of fusidic acid resistance. Clin. Infect. Dis. 2011, 52, S487-S492. [CrossRef]

56. Barton, L.L.; Fardeau, M.-L.; Fauque, G.D. Hydrogen sulfide: A toxic gas produced by dissimilatory sulfate and sulfur reduction and consumed by microbial oxidation. In The Metal-Driven Biogeochemistry of Gaseous Compounds in the Environment; Springer: Cham, Switerland, 2014; pp. 237-277.

57. Su, X.; Wellen, K.E.; Rabinowitz, J.D. Metabolic control of methylation and acetylation. Curr. Opin. Chem. Biol. 2016, 30, 52-60. [CrossRef]

58. Adhikari, S.; Curtis, P.D. DNA methyltransferases and epigenetic regulation in bacteria. FEMS Microbiol. Rev. 2016, 40, 575-591. [CrossRef]

59. Fortin, D.; Davis, B.; Beveridge, T. Role of Thiobacillus and sulfate-reducing bacteria in iron biocycling in oxic and acidic mine tailings. FEMS Microbiol. Ecol. 1996, 21, 11-24. [CrossRef]

60. White, C.; Gadd, G. Copper accumulation by sulfate-reducing bacterial biofilms. FEMS Microbiol. Lett. 2000, 183, 313-318. [CrossRef] [PubMed]

61. Yin, W.; Wang, Y.; Liu, L.; He, J. Biofilms: The microbial "protective clothing" in extreme environments. Int. J. Mol. Sci. 2019, 20, 3423. [CrossRef]

62. Gadd, G. Heavy metal pollutants: Environmental and biotechnological aspects. In Encyclopedia of Microbiology; Elsevier: Amsterdam, The Netherlands, 2009; pp. 321-334.

63. Utgikar, V.P.; Harmon, S.M.; Chaudhary, N.; Tabak, H.H.; Govind, R.; Haines, J.R. Inhibition of sulfate-reducing bacteria by metal sulfide formation in bioremediation of acid mine drainage. Environ. Toxicol. 2002, 17, 40-48. [CrossRef]

64. Gu, T.; Zhao, K.; Nesic, S. A new mechanistic model for MIC based on a biocatalytic cathodic sulfate reduction theory. In Proceedings of the Corrosion Conference and Expo 2009, Atlanta, GA, USA, 22-26 March 2009.

65. Bijmans, M.F.; Dopson, M.; Peeters, T.W.; Lens, P.N.; Buisman, C.J. Sulfate reduction at pH 5 in a high-rate membrane bioreactor: Reactor performance and microbial community analyses. J. Microbiol. Biotechnol. 2009, 19, 698-708. [CrossRef]

66. Bayraktarov, E.; Price, R.E.; Ferdelman, T.G.; Finster, K. The $\mathrm{pH}$ and $\mathrm{pCO}_{2}$ dependence of sulfate reduction in shallow-sea hydrothermal $\mathrm{CO}_{2}$-venting sediments (Milos Island, Greece). Front. Microbiol. 2013, 4, 111. [CrossRef]

67. Reis, M.; Almeida, J.; Lemos, P.; Carrondo, M. Effect of hydrogen sulfide on growth of sulfate reducing bacteria. Biotechnol. Bioeng. 1992, 40, 593-600. [CrossRef]

68. Hao, O.J.; Chen, J.M.; Huang, L.; Buglass, R.L. Sulfate-reducing bacteria. Crit. Rev. Environ. Sci. Technol. 1996, $26,155-187$. [CrossRef]

69. Moosa, S.; Harrison, S. Product inhibition by sulphide species on biological sulphate reduction for the treatment of acid mine drainage. Hydrometallurgy 2006, 83, 214-222. [CrossRef]

70. Banciu, H.L.; Sorokin, D.Y. Adaptation in haloalkaliphiles and natronophilic bacteria. In Polyextremophiles; Springer: Cham, Switerland, 2013; pp. 121-178.

71. Gomes, H.I.; Mayes, W.M.; Rogerson, M.; Stewart, D.I.; Burke, I.T. Alkaline residues and the environment: A review of impacts, management practices and opportunities. J. Clean. Prod. 2016, 112, 3571-3582. [CrossRef]

72. Goeres, D.; Nielsen, P.H.; Smidt, H.; Frølund, B. The effect of alkaline pH conditions on a sulphate reducing consortium from a Danish district heating plant. Biofouling 1998, 12, 273-286. [CrossRef]

73. Stolyar, S.; He, Q.; Joachimiak, M.P.; He, Z.; Yang, Z.K.; Borglin, S.E.; Joyner, D.C.; Huang, K.; Alm, E.; Hazen, T.C. Response of Desulfovibrio vulgaris to alkaline stress. J. Bacteriol. Res. 2007, 189, 8944-8952. [CrossRef] [PubMed]

74. Dilworth, M.; Glenn, A. Problems of Adverse $p H$ and Bacterial Strategies to Combat It; Wiley: Chichester, UK, 1999. 
75. Skulachev, V.P.; Kobayashi, H.; Krulwich, T.; Schafer, G.; Fillingame, R.; Poole, R.; Cook, G.; Dimroth, M.; Konings, W.; Stock, J. Bacterial energetics at high $\mathrm{pH}$ : What happens to the $\mathrm{H}^{+}$cycle when the extracellular $\mathrm{H}^{+}$concentration decreases? In Novartis Foundation Symposium; Wiley: Chichester, UK, 1999; pp. 200-217.

76. Saito, H.; Kobayashi, H. Bacterial responses to alkaline stress. Sci. Prog. 2003, 86, 271-282. [CrossRef]

77. Hicks, D.B.; Liu, J.; Fujisawa, M.; Krulwich, T.A. F1F0-ATP synthases of alkaliphilic bacteria: Lessons from their adaptations. Biochim. Biophys. Acta 2010, 1797, 1362-1377. [CrossRef] [PubMed]

78. Mitchell, P. Coupling of phosphorylation to electron and hydrogen transfer by a chemiosmotic type of mechanism. Nature 1961, 191, 144-148. [CrossRef]

79. Mitchell, P. Molecule, group and electron translocation through natural membranes. Biochem. J. 1962, 83, 22.

80. Slonczewski, J.L.; Fujisawa, M.; Dopson, M.; Krulwich, T.A. Cytoplasmic pH measurement and homeostasis in bacteria and archaea. Adv. Microb. Physiol. 2009, 55, 1-317.

81. Vanhauteghem, D.; Janssens, G.P.J.; Lauwaerts, A.; Sys, S.; Boyen, F.; Cox, E.; Meyer, E. Exposure to the proton scavenger glycine under alkaline conditions induces Escherichia coli viability loss. PLoS ONE 2013, 8, e60328. [CrossRef]

82. Mueller, E.A.; Egan, A.J.; Breukink, E.; Vollmer, W.; Levin, P.A. Plasticity of Escherichia coli cell wall metabolism promotes fitness and antibiotic resistance across environmental conditions. Elife 2019, 8, e40754. [CrossRef]

83. Aono, R.; Ito, M.; Machida, T. Contribution of the cell wall component teichuronopeptide to $\mathrm{pH}$ homeostasis and alkaliphily in the alkaliphile Bacillus lentus C-125. J. Bacteriol. 1999, 181, 6600-6606. [CrossRef] [PubMed]

84. Calabretta, P.J.; Hodges, H.L.; Kraft, M.B.; Marando, V.M.; Kiessling, L.L. Bacterial cell wall modification with a glycolipid substrate. J. Am. Chem. Soc. 2019, 141, 9262-9272. [CrossRef] [PubMed]

85. Stancik, L.M.; Stancik, D.M.; Schmidt, B.; Barnhart, D.M.; Yoncheva, Y.N.; Slonczewski, J.L. pH-dependent expression of periplasmic proteins and amino acid catabolism in Escherichia coli. J. Bacteriol. 2002, 184, 4246-4258. [CrossRef] [PubMed]

86. Bevilacqua, A.; Sinigaglia, M.; Corbo, M.R. An acid/alkaline stress and the addition of amino acids induce a prolonged viability of Lactobacillus plantarum loaded into alginate gel. Int. J. Food Microbiol. 2010, 142, 242-246. [CrossRef]

87. Al Shoffe, Y. Susceptibility and Expression of Chilling Injury. In Reference Module in Food Science; Elsiver: Amsterdam, The Netherlands, 2018.

88. Li, X.; Luo, Q.; Wofford, N.Q.; Keller, K.L.; McInerney, M.J.; Wall, J.D.; Krumholz, L.R. A molybdopterin oxidoreductase is involved in $\mathrm{H}_{2}$ oxidation in Desulfovibrio desulfuricans G20. J. Bacteriol. 2009, 191, 2675-2682. [CrossRef] [PubMed]

89. Fu, W.; Mathews, A. Lactic acid production from lactose by Lactobacillus plantarum: Kinetic model and effects of $\mathrm{pH}$, substrate, and oxygen. Biochem. Eng. J. 1999, 3, 163-170. [CrossRef]

90. Rahmani, A.; Mathien, C.; Bidault, A.; Le Goïc, N.; Paillard, C.; Pichereau, V. External pH modulation during the growth of Vibrio tapetis, the etiological agent of Brown Ring Disease. J. Appl. Microbiol. 2020, 129, 3-16. [CrossRef]

91. Cao, J.; Zhang, G.; Mao, Z.; Fang, Z.; Yang, C. Precipitation of valuable metals from bioleaching solution by biogenic sulfides. Miner. Eng. 2009, 22, 289-295. [CrossRef]

92. Berner, R. Sulphate reduction, organic matter decomposition and pyrite formation. Philos. Trans. Royal Soc. A 1985, 315, 25-38.

93. Glombitza, C.; Stockhecke, M.; Schubert, C.J.; Vetter, A.; Kallmeyer, J. Sulfate reduction controlled by organic matter availability in deep sediment cores from the saline, alkaline Lake Van (Eastern Anatolia, Turkey). Front. Microbiol. 2013, 4, 209. [CrossRef] [PubMed]

94. Curtin, D.; Campbell, C.; Jalil, A. Effects of acidity on mineralization: pH-dependence of organic matter mineralization in weakly acidic soils. Soil Biol. Biochem. 1998, 30, 57-64. [CrossRef]

95. Curtin, D.; Peterson, M.E.; Anderson, C.R. pH-dependence of organic matter solubility: Base type effects on dissolved organic C, $\mathrm{N}, \mathrm{P}$, and S in soils with contrasting mineralogy. Geoderma 2016, 271, 161-172. [CrossRef]

96. Jones, D.; Amy, P. A thermodynamic interpretation of microbiologically influenced corrosion. Corrosion 2002, 58, 638-645. [CrossRef]

97. Little, B.J.; Lee, J.S. Microbiologically Influenced Corrosion; John Wiley \& Sons: Hoboken, NJ, USA, 2007 ; Volume 3.

98. Viles, H. Acid corrosion (of stone and metal). In Environmental Geology. Encyclopedia of Earth Science; Springer: Dordrecht, The Netherlands, 1999.

99. Panossian, Z.; de Almeida, N.L.; de Sousa, R.M.F.; de Souza Pimenta, G.; Marques, L.B.S. Corrosion of carbon steel pipes and tanks by concentrated sulfuric acid: A review. Corros. Sci. 2012, 58, 1-11. [CrossRef]

100. Mehmeti, V.V.; Berisha, A.R. Corrosion study of mild steel in aqueous sulfuric acid solution using 4-methyl-4H-1, 2, 4-Triazole-3Thiol and 2-mercaptonicotinic acid-an experimental and theoretical study. Front. Chem. 2017, 5, 61. [CrossRef]

101. Damon, G.H. Acid corrosion of steel. J. Ind. Eng. Chem. 1941, 33, 67-69. [CrossRef]

102. Ismail, M.; Noor, N.M.; Yahaya, N.; Abdullah, A.; Rasol, R.M.; Rashid, A.S.A. Effect of pH and temperature on corrosion of steel subject to sulphate-reducing bacteria. Environ. Sci. Technol. 2014, 7, 209-217. [CrossRef]

103. Iliyasu, I.; Yawas, D.; Aku, S. Corrosion behavior of austenitic stainless steel in sulphuric acid at various concentrations. Adv. Appl. Sci. Res. 2012, 3, 3909-3915.

104. Beech, I.B. Sulfate-reducing bacteria in biofilms on metallic materials and corrosion. Microbiol. Today 2003, 30, $115-117$.

105. Tamura, $\mathrm{H}$. The role of rusts in corrosion and corrosion protection of iron and steel. Corros. Sci. 2008, 50, 1872-1883. [CrossRef]

106. Zuo, R.; Kus, E.; Mansfeld, F.; Wood, T.K. The importance of live biofilms in corrosion protection. Corros. Sci. 2005, 47, 279-287. [CrossRef]

107. Nagiub, A.; Mansfeld, F. Evaluation of microbiologically influenced corrosion inhibition (MICI) with EIS and ENA. Electrochim. Acta. 2002, 47, 2319-2333. [CrossRef] 
108. Jayaraman, A.; Earthman, J.; Wood, T.K. Corrosion inhibition by aerobic biofilms on SAE 1018 steel. Appl. Microbiol. Biotechnol. 1997, 47, 62-68. [CrossRef]

109. Chongdar, S.; Gunasekaran, G.; Kumar, P. Corrosion inhibition of mild steel by aerobic biofilm. Electrochim. Acta. 2005, 50, 4655-4665. [CrossRef]

110. Talukdar, A.; Rajaraman, P.V. Investigation of Acetic Acid Effect on Carbon Steel Corrosion in $\mathrm{CO}_{2}-\mathrm{H}_{2} \mathrm{~S}$ Medium: Mechanistic Reaction Pathway and Kinetics. ACS Omega 2020, 5, 11378-11388. [CrossRef] [PubMed]

111. Pak, K.-R.; Lee, H.-J.; Lee, H.-K.; Kim, Y.-K.; Oh, Y.-S.; Choi, S.-C. Involvement of organic acid during corrosion of iron coupon by Desulfovibrio desulfuricans. J. Microbiol. Biotechnol. 2003, 13, 937-941.

112. Xin, L.; Xu, C.; Wuqi, S.; Jiaxing, Y.; Ming, W. Effect of pH Value on Microbial Corrosion Behavior of X70 Steel in a Sea Mud Extract Simulated Solution. J. Chin. Soc. Corros. Sci. Prot. 2019, 38, 565-572.

113. Speller, F.; Texter, C. Effect of Alkaline Solutions on the Corrosion of Steel Immersed in Water. Ind. Eng. Chem. Res. 1924, 16, 393-397. [CrossRef]

114. Luo, H.; Dong, C.; Li, X.; Xiao, K. The electrochemical behaviour of 2205 duplex stainless steel in alkaline solutions with different $\mathrm{pH}$ in the presence of chloride. Electrochim. Acta. 2012, 64, 211-220. [CrossRef]

115. Tang, D.Z.; Du, Y.X.; Lu, M.X.; Liang, Y.; Jiang, Z.T.; Dong, L. Effect of pH value on corrosion of carbon steel under an applied alternating current. Mater. Corros. 2015, 66, 1467-1479. [CrossRef]

116. Smart, N.; Rance, A.; Nixon, D.; Fennell, P.; Reddy, B.; Kursten, B. Summary of studies on the anaerobic corrosion of carbon steel in alkaline media in support of the Belgian supercontainer concept. Corros. Eng. Sci. Technol. 2017, 52, 217-226. [CrossRef]

117. Senior, N.A.; Martino, T.; Diomidis, N. The anoxic corrosion behaviour of carbon steel in anoxic alkaline environments simulating a Swiss L/ILW repository environment. Mater. Corros. 2020, 72, 131-140. [CrossRef]

118. King, F. Corrosion of Copper in Alkaline Chloride Environments; Swedish Nuclear Fuel and Waste Management Co.: Hoboken, NJ, USA, 2002.

119. Tabrizi, M.; Lyon, S.; Thompson, G.; Ferguson, J. The long-term corrosion of aluminium in alkaline media. Corros. Sci. 1991, 32, 733-742. [CrossRef]

120. Król, A.; Mizerna, K.; Bożym, M. An assessment of pH-dependent release and mobility of heavy metals from metallurgical slag. J. Hazard. Mater. 2020, 384, 121502. [CrossRef]

121. Giron, R.G.P.; Chen, X.; La Plante, E.C.; Gussev, M.N.; Leonard, K.J.; Sant, G. Revealing how alkali cations affect the surface reactivity of stainless steel in alkaline aqueous environments. ACS Omega 2018, 3, 14680-14688. [CrossRef]

122. Betova, I.; Bojinov, M.; Hyökyvirta, O.; Saario, T. Effect of sulphide on the corrosion behaviour of AISI 316L stainless steel and its constituent elements in simulated Kraft digester conditions. Corros. Sci. 2010, 52, 1499-1507. [CrossRef]

123. Wiener, M.S.; Salas, B.; Quintero-Nunez, M.; Zlatev, R. Effect of $\mathrm{H}_{2} \mathrm{~S}$ on corrosion in polluted waters: A review. Corros. Eng. Sci. Technol. 2006, 41, 221-227. [CrossRef]

124. Davoodi, A.; Pakshir, M.; Babaiee, M.; Ebrahimi, G.R. A comparative $\mathrm{H}_{2} \mathrm{~S}$ corrosion study of $304 \mathrm{~L}$ and $316 \mathrm{~L}$ stainless steels in acidic media. Corros. Sci. 2011, 53, 399-408. [CrossRef]

125. Starosvetsky, D.; Starosvetsky, J.; Armon, R.; Ein-Eli, Y. A peculiar cathodic process during iron and steel corrosion in sulfate reducing bacteria (SRB) media. Corros. Sci. 2010, 52, 1536-1540. [CrossRef]

126. Park, J.O.; Böhni, H. Local pH measurements during pitting corrosion at MnS inclusions on stainless steel. Electrochem. Solid. St. 2000, 3, 416-417. [CrossRef]

127. Williams, D.E.; Kilburn, M.R.; Cliff, J.; Waterhouse, G. Composition changes around sulphide inclusions in stainless steels, and implications for the initiation of pitting corrosion. Corros. Sci. 2010, 52, 3702-3716. [CrossRef]

128. Venzlaff, H.; Enning, D.; Srinivasan, J.; Mayrhofer, K.J.; Hassel, A.W.; Widdel, F.; Stratmann, M. Accelerated cathodic reaction in microbial corrosion of iron due to direct electron uptake by sulfate-reducing bacteria. Corros. Sci. 2013, 66, 88-96. [CrossRef]

129. Abdullah, A.; Yahaya, N.; Md Noor, N.; Mohd Rasol, R. Microbial corrosion of API 5L X-70 carbon steel by ATCC 7757 and consortium of sulfate-reducing bacteria. J. Chem. 2014, 2014. [CrossRef]

130. Musić, S.; Nowik, I.; Ristić, M.; Orehovec, Z.; Popović, S. The effect of bicarbonate/carbonate ions on the formation of iron rust. Croat. Chem. Acta. 2004, 77, 141-151.

131. Troup, D.; Richardson, J. The Link Between the Corrosion and calcium carbonate scaling susceptibilities of heat transfer surfaces. Mater. Corros. 1978, 29, 312-320. [CrossRef]

132. Ahmad, E.A.; Chang, H.-Y.; Al-Kindi, M.; Joshi, G.R.; Cooper, K.; Lindsay, R.; Harrison, N.M. Corrosion protection through naturally occurring films: New insights from iron carbonate. ACS Appl. Mater. Interfaces 2019, 11, 33435-33441. [CrossRef]

133. Li, S.; Zeng, Z.; Harris, M.A.; Sánchez, L.J.; Cong, H. $\mathrm{CO}_{2}$ corrosion of low carbon steel under the joint effects of time-temperaturesalt concentration. Front. Mater. 2019, 6, 10. [CrossRef]

134. Schaller, R.F.; Jove-Colon, C.F.; Taylor, J.M.; Schindelholz, E.J. The controlling role of sodium and carbonate on the atmospheric corrosion rate of aluminum. NPJ Mater. Degrad. 2017, 1, 1-8. [CrossRef]

135. Powell, S.T.; Bacon, H.; Lill, J. Corrosion prevention by controlled calcium carbonate scale. J. Ind. Eng. Chem. 1945, 37, 842-846. [CrossRef]

136. Esmaeely, S.N.; Choi, Y.-S.; Young, D.; Nesic, S. Effect of Calcium on the Formation and Protectiveness of the Iron Carbonate Layer in CO2 Corrosion; Ohio University: Athens, OH, USA, 2013. 